\title{
HIGIENE GENETALIA SEBAGAI FAKTOR RISIKO TERJADINYA INFEKSI MENULAR SEKSUAL PADA IBU RUMAH TANGGA ( Studi Kasus Puskesmas Bandarharjo Semarang)
}

\author{
Kumalasari, Anies, Henry Setyawan, \\ Bagoes Widjanarko, Muchlis A.U. Sofro
}

\begin{abstract}
ABSTRAK
Latar Belakang : IMS mengakibatkan masalah kesehatan seksual dan reproduksi yang berdampak kepada kalangan perempuan terutama ibu rumah tangga, anak-anak dan orang-orang miskin. Faktor yang dapat mempengaruhi kejadian IMS meliputi semua aspek epidemiologi: umur, ras, pendidikan, pekerjaan, status ekonomi, status perkawinan, pengetahuan, sikap dan praktik dalam perawatan higiene genetalia. Puskesmas Bandarharjo memiliki angka kejadian IMS yang cukup tinggi 50 kasus di tahun 2014 dan 90\% adalah ibu rumah tangga. Penelitian ini ingin membuktikan faktor higiene genetalia berpengaruh terhadap kejadian IMS pada ibu rumah tangga.

Metode : Penelitian ini menggunakan pendekatan mix method dengan desain studi kasus-kontrol, jumlah sampel sebanyak 80 dengan perbandingan 1:1 (40 responden masing-masing kelompok), di wilayah kerja Puskesmas Bandarharjo. Sebagai kasus adalah ibu rumah tangga yang positif IMS dan kontrol adalah ibu rumah tangga yang negatif IMS setelah diperiksa secara fisik dan laboratorium di Puskesmas Bandarharjo. Data di analisis secara univariat, bivariat (chi-square), dan multivariat (regresi logistik), dilanjutkan indepthinterview.

Hasil : Beberapa faktor yang terbukti berpengaruh terhadap IMS pada Ibu rumah tangga adalah tidak cebok sebelum melakukan hubungan seksual $(\mathrm{OR}=7,7 ; 95 \%$ CI 2,0-29,1; $\mathrm{p}=0,002)$, vaginal douching $(\mathrm{OR}=7,7$; 95\% CI 2,0-29,1; $\mathrm{p}=0,002)$, Pendapatan keluarga rendah < UMR (OR=4,0; 95\% CI 1,4-14,3; $\mathrm{p}=0,030)$.

Simpulan : Faktor higiene genetalia yang berpengaruh terhadap IMS pada Ibu rumah tangga adalah tidak cebok sebelum HUS, melakukan vaginal douching, pendapatan keluarga < UMR.
\end{abstract}

Kata Kunci : IMS, Ibu rumah tangga, Higiene genetalia.

\begin{tabular}{|c|c|}
\hline PENDAHULUAN & dikeluarkan \\
\hline Infeksi Menular Seksual (IMS) adalah penyakit & Organization (WHO) tahun 2013, lebih dari satu juta orang \\
\hline yang timbul atau ditularkan melalui hubungan seksual (1- & memperoleh infeksi menular seksual setiap hari. Setiap \\
\hline 2), yang sebagian besar menular lewat hubungan seksual & tahunnya sekitar 500 juta orang menjadi sakit dengan salah \\
\hline dengan pasangan yang sudah tertular, namun ini hanya & satu dari empat jenis infeksi menular seksual, yaitu \\
\hline menunjuk pada penyakit yang ada dikelamin. Istilah IMS & klamidia, gonore, sifilis,dan trikomoniasis. Lebih dari 290 \\
\hline lebih luas maknanya, karena menunjuk pada cara & juta wanita memiliki human papilloma virus $(5,6)$. \\
\hline penularannya(3). IMS dapat mengakibatkan masalah yang & Berdasarkan data dikalangan kelompok berisiko tinggi di \\
\hline besar dalam kesehatan masyarakat terutama konsekuensi & Indonesia, telah memberikan gambaran bahwa telah \\
\hline terhadap kesehatan seksual dan reproduksi yang lebih & terjadi peningkatan prevalensi pada tahun 2011 lelaki seks \\
\hline berdampak kepada kalangan perempuan, anak-anak dan & dengan lelaki (LSL) $12 \%$, lelaki beresiko tinggi $0,7 \%$ pada \\
\hline orang-orang miskin(4). & ensi gonorhoe dan atau klamida pada \\
\hline Faktor yang dapat mempengaruhi kejadian IMS & wanita penjaja seks langsung (WPSL) sebesar $56 \%$ pada \\
\hline meliputi semua aspek epidemiologi yaitu umu & tidak langsung (WPSTL) pada to \\
\hline pendidikan, pekerjaan, status ekonomi, status perkawinan, & 2011 sebesar 47\% (7). Penderita IMS di Propinsi Jawa \\
\hline $\begin{array}{l}\text { pengetahuan sikap dan praktik dalam perawatan higiene } \\
\text { genetalia(5) }\end{array}$ & Tengah pada tahun 2011 sebanyak 10.752 kasus. Kasus \\
\hline $\begin{array}{c}\text { Perawatan area genetalia sangat jarang } \\
\text { dibicarakan oleh masyarakat Indonesia karena terkesan }\end{array}$ & $\begin{array}{l}\text { IMS di kota Semarang pada tahun } 2014 \text { angka kesakitan } \\
\text { akibat IMS yaitu sebanyak } 5749 \text { kasus }(8) \text {. }\end{array}$ \\
\hline tabu dan jorok. Higiene genetalia adalah perawatan & Kurangnya kesadaran dari masyarakat \\
\hline kebersihan alat kelamin khususnya pada perempuan & dini terhadap kesehatan \\
\hline tetap terjaga keseimbangan flora normal dalam vagina(2).. & reproduksi termasuk IMS di Puskesmas Bandarharjo \\
\hline
\end{tabular}


terbukti dari cakupan pemeriksaan pada klinik IMS hanya $42 \%$ dan lebih dari $90 \%$ perempuan yang berstatus sebagai ibu rumah tangga. Hasil pemeriksaan yang dilakukan oleh dokter yang bertugas di klinik IMS tersebut maka didapatkan sekitar 60\% ibu rumah tangga yang datang menderita vaginitis(8). Berdasarkan data diatas sebelumnya belum pernah dilakukan penelitian pada perempuan khususnya ibu rumah tangga, oleh karena itu maka peneliti tertarik untuk melakukan penelitian dan ingin meneliti lebih jauh mengenai, "Higiene genetalia merupakan faktor risiko terjadinya IMS" studi kasus pada ibu rumah tangga yang berada di wilayah kerja Puskesmas Bandarharjo Semarang.

\section{METODE PENELITIAN}

Rancangan penelitian ini mix method dimana kuantitatif adalah sebagai pendekatan utamanya dan kualitatif adalah pendekatan pendukung. Menggunakan desain kasus-kontrol, dan wawancara mendalam (in-deptinterview).

Populasi rujukan adalah seluruh ibu rumah tangga yang terdiagnosa IMS di kota Semarang. Populasi studi adalah ibu rumah tangga yang terdiagnosa IMS di klinik IMS Puskesmas Bandarharjo Semarang. Sampel responden kasus adalah ibu rumah tangga terdiagnosa IMS di klinik IMS Puskesmas Bandarharjo Semarang, dan kasus kontrol adalah ibu rumah tangga yang tidak terdiagnosa IMS di klinik IMS Puskesmas Bandarharjo Semarang.

Cara pemilihan sampel adalah dengan "purposive sampling" yaitu setiap subjek yang memenuhi kriteria penelitian dimasukkan dalam penelitian sampai kurun waktu tertentu sehingga jumlah sampel terpenuhi. ${ }^{(9)}$.

Total sampel/responden dalam penelitian ini adalah 80 orang, dengan perbandingan 1:1. Maka didapati 40 kasus dan 40 kontrol.

Kriteria inklusi kasus adalah ibu rumah tangga bertempat tinggal di wilayah kerja Puskesmas Bandarharjo terdiagnosa IMS di klinik IMS Puskesmas Bandarharjo dan bersedia berpartisipasi menjadi responden dengan informed consent. Kriteria eksklusi kasus adalah ibu rumah tangga yang tinggal di wilayah kerja Puskesmas Bandarharjo terdiagnosa IMS tetapi tidak dilakukan di Puskesmas Bandarharjo dan tidak mau berpartisispasi menjadi responden. Untuk kriteria inklusi kontrol adalah ibu rumah tangga yang bertempat tinggal di wilayah kerja Puskesmas Bandarharjo memanfaatkan pelayanan Puskesmas dan tidak terdiagnosa IMS di klinik IMS Puskesmas Bandarharjo serta bersedia menjadi responden dengan informed consent. Kriteria eksklusi kontrol adalah ibu rumah tangga yang tidak tinggal di wilayah kerja Puskesmas Bandarharjo memanfaatkan pelayanan Puskesmas, dan tidak bersedia menjadi responden.

Variabel terikat adalah IMS, variabel bebas adalah umur, pendidikan, pengetahuan, status ekonomi, vagina douching, cebok genetalia sebelum HUS, cebok genetalia setelah HUS, mengeringkan genetalia setelah cebok, penggantian celana dalam, bahan celana dalam yang digunakan, pencukuran rambut genetalia, alat cukur manual yang digunakan untuk mencukur, pemakaian celana ketat (legging), frekuensi mengganti pembalut saat menstruasi kurang dari 2 kali dalam sehari.

Pengolahan dan analisis data dilakukan dengan sistem komputer program SPSS 16.0 terdiri dari analisis univariat, bivariat menggunakan uji chi-squre, dan multivariat dengan regresi logistik ganda dilanjutkan indepht-interview.

\section{HASIL PENELITIAN}

Dari penelitian yang dilakukan pada bulan JuliAgustus 2015 di wilayah kerja Puskesmas Bandarharjo Semarang pada 80 responden diperoleh hasil dengan analisa univariat, bivariat, dan multivariat sebagai berikut.

Tabel 1 menunjukkan sebagian besar responden sebanyak $95 \%$ berusia $\geq 25$ tahun, dengan pendidikan terakhir responden sebagian besar adalah tamat SLTA (46,25\%), sebagian besar responden memiliki pengetahuan yang baik $\quad(52,2 \%)$ tentang IMS, sebagian besar responden $(52,5 \%)$ memiliki pendapatan keluarga yang rendah <UMR $(<1.685 .000)$, sebagian besar responden bertempat tinggal di Kelurahan Bandarharjo (41,25\%), responden yang melakukan vaginal douching 67,5\% sering melakukan dan $70 \%$ menggunakan air dan larutan antiseptik, 22,5\% menggunakan pasta gigi, 7,5 dengan cuka dan larutan baking soda, 70\% responden melakukan setelah HUS 69,2\% setelah menstruasi $10 \%$ juga melakukan gurah vagina. Sebagian besar responden tidak cebok sebelum HUS $(58,8)$, sebagian besar responden setelah HUS melakukan cebok $(96,2 \%)$, sebagian besar responden tidak keringkan genetalia setelah cebok $(52,5 \%)$, sebagian besar responden mengganti celana dalam saat basah(66,2\%), sebagian besar responden menggunakan celana dalam dari bahan katun $(83,8 \%)$, penggunaan celana ketat atau legging pada terbagi rata yaitu 50\% menggunakan dan 50\% tidak menggunakan. Sebagian responden melakukan pencukuran pada rambut genetalia $(60 \%)$ dan menggunakan alat cukur manual (52,5\%), sebagian besar responden mengganti pambalut saat menstruasi lebih dari dua kali $(93,8 \%)$.

Analisis bivariat (Tabel 2) menunjukkan bahwa faktor higiene yang berpengaruh terhadap terjadinya IMS pada ibu rumah tangga adalah tidak mengeringkan genetalia setelah cebok $(\mathrm{OR}=5,4 ; \mathrm{p}=0,000)$, melakukan vaginal douching $(\mathrm{OR}=11 ; \mathrm{p}=0,000)$, tidak cebok sebelum HUS $(\mathrm{OR}=5,1 ; \mathrm{p}=0,001)$, menggunakan legging $(\mathrm{OR}=5,4 ; \mathrm{p}=0,001)$, tingkat pendapatan keluarga rendah <UMR ( $\mathrm{OR}=4,3 ; \mathrm{p}=0,004)$ tidak segera ganti celana dalam saat basah $(\mathrm{OR}=4,7 \mathrm{p}=0,005)$ dan didapati satu variabel yang tidak signifikan dengan nilai $\quad \mathrm{p}=0,225$ yaitu bahan celana dalam yang digunakan, karena $p<0,25$ sehingga variabel tersebut dapat masuk dalam model multivariat.

Analisis multivariat (tabel 3) mendapati bahwa variabel higiene genetalia yang berpengaruh terhadap terjadinya IMS pada ibu rumah tangga adalah tidak cebok sebelum HUS (OR 7,7: $\mathrm{p}=0,002$ ), melakukan vaginal douching $(\mathrm{OR}=6,5 \mathrm{p}=0,004)$, pendapatan keluarga rendah $<\mathrm{UMR}$ (OR 4,0; $\mathrm{p}=0,030)$. Hasil perhitungan persamaan MLR menunjukkan bahwa ibu rumah tangga yang tidak cebok sebelum melakukan HUS, melakukan vaginal 
douching, dan memiliki pendapatan keluarga yang rendah $<$ UMR memiliki probabilitas atau risiko mengalami kejadian Infeksi Menular Seksual sebesar 79,80\%.

\section{PEMBAHASAN}

Analisis multivariat menyatakan bahwa ibu rumah tangga yang tidak cebok sebelum melakukan HUS memiliki risiko terkena IMS 7,7 kali dibanding ibu rumah tangga yang cebok sebelum HUS( $p=0,002$; CI 95\% 2,0-29,1). Hasil ini sejalan dengan penelitian FN. Amiri dkk yang telah membuktikan bahwa adanya hubungan antara IMS yang disebabkan oleh bakteri maupun jamur akibat tidak cebok sebelum melakukan hubungan seksual $\mathrm{p}=0,001(\mathrm{OR}=2.1695 \% \mathrm{CI}: 1,29$ $3,63)^{(10)}$. Vagina merupakan organ reproduksi wanita yang sangat rentan terhadap infeksi. Hal ini disebabkan batas antar uretra dengan anus sangat dekat, sehingga kuman penyakit seperti jamur, bakteri, parasit, maupun virus mudah masuk keliang vagina. Untuk itu wanita harus rajin merawat kebersihan wilayah pribadinya. Pasangan yang tidak membersihkan alat kelaminnya sebelum melakukan hubungan seks maka bakteri dari kedua pasangan bisa masuk ke alat kelamin perempuan dan berkembang biak disana, akibatnya akan mengganggu flora normal vagina sehingga dapat sebabkan IMS ${ }^{(10)}$. Sebagian besar dari responden memberikan pernyataan tidak mencuci genetalia sebelum melakukan hubungan seksual dikarenakan ngantuk bahkan malas.

“......Ngantuk mba, udah gak kepikiran cebok yang penting suami minta kita kasi aja sambil mata riyipriyip"

Hasil multivariat menyatakan bahwa ibu rumah tangga yang melakukan vaginal douching memiliki risiko 6,5 kali dibanding ibu rumah tangga yang tidak melakukan vaginal douching $\quad(\mathrm{p}=0,00495 \% \mathrm{CI}: 1,8-18,2)$. Hasil ini sejalan dengan penelitian tentang Praktek vaginal douching pada perempuan hitam yang berisiko, dan penyakit IMS. Dengan melakukan douching berisiko terkena Klamidia dan Gonorhhoe $(\mathrm{OR}=3,66 ; 95 \% \mathrm{CI}$ : 1,00-13,41) (11). Vaginal douching adalah mencuci atau membersihkan vagina bagian dalam dengan cara menyemprotkan air atau cairan campuran yang terdiri atas air dan cuka, baking soda, atau yodium, maupun sabun. Campuran tersebut biasanya dikemas dalam botol dan dapat disemprotkan ke dalam vagina melalui tabung atau nozzle. Lingkungan vagina yang sehat mengandung Lactobacillus yaitu jenis bakteri dan organisme khusus, yang berguna untuk menjaga tingkat keasaman saluran bagian penting tubuh wanita. Tingkat keasaman yang normal berfungsi untuk menjaga keseimbangan jumlah bakteri yang berbahaya tetap rendah. Dengan melakukan douching, hal ini akan mengubah keseimbangan asam yang ada didalamnya, sehingga dapat membuat wanita lebih rentan terkena IMS. Disamping itu, douching bisa menyebarkan infeksi yang ada sampai ke rahim, saluran tuba, dan ovarium ${ }^{(12)}$. Berdasarkan hasil wawancara mendalam dengan responden sebagian besar dari responden melakukan vaginal douching karena mereka berpendapat bahwa dengan melakukan douching dapat untuk membersihkan vagina dari bau tidak sedap, membilas darah setelah menstruasi, membersihkan sperma setelah HUS , membunuh bakteri sehingga bisa mencegah tertularnya penyakit menular seksual (IMS) yang dibawa oleh suaminya.

“.....udah biasa mbak saya rutin kok membersihkan vagina saya, biasanya saya pake sabun sirih,caranya ambil gayung yang ada airnya terus ditetesin sabun sirih yang cair to, terus disiramkan dikit jariku masuk tak korek-korek klo udah keluar lendir e tak bilas, aku biasanya tiap hari mba, apalagi klo habis diajak kumpul bapak e yo langsung tak bersihin lagi"

Hasil multivariat menyatakan bahwa ibu rumah tangga yang memiliki pendapatan keluarga rendah <UMR (<1.685.000,-) memiliki risiko terjadinya IMS sebesar 4,05 kali lebih besar dibanding dengan ibu rumah tangga yang pemghasilan keluarganya lebih $\geq$ UM ( $\geq 1.685 .000,-)$. Hal ini sejalan dengan penelitian yang dilakukan oleh Holthgrave dan Crosby tentang modal sosial, kemiskinan, dan ketimpangan pendapatan sebagai prediktor Gonore, Sifilis, Klamidia dan tingkat kasus AIDS di Amerika Serikat, kemiskinan secara signifikan berhubungan dengan Klamidia, Gonore, Sifilis. Klamidia dan tingkat kasus AIDS dengan $\mathrm{p}=0,001$. Ketimpangan pendapatan secara signifikan berhubungan dengan meningkatkan kejadian klamidia dan kasus AIDS $\mathrm{p}=0,001^{(12)}$.

Karena perempuan tidak memiliki kekuatan sosial dan ekonomi serta ketergantungan ekonomi perempuan pada kepala keluarga sehingga mereka tidak mempunyai posisi tawar dan sulit untuk mengontrol agar dirinya terlindungi tidak terinfeksi oleh IMS, karena dirinya tidak bisa menolak berhubungan atau menyuruh suaminya menggunakan alat pengaman ${ }^{(13)}$. Berdasarkan hasil wawancara mendalam tentang pendapatan keluarga yang didapat oleh keluarga responden, rata-rata responden menggantungkan pendapatan ekonomi dari suami yang mana hasil atau upah yang didapat kurang dari UMR $(<1.685 .000$,).

“.....saya tidak kerja mbak, suami kerjanya serabutan kalo ada yang butuh tenaganya baru dapat kerja mba,maklum kerjanya tukang batu jadi kenek"

Variabel yang tidak terbukti berpengaruh terhadap IMS pada ibu rumah tangga adalah tidak mengeringkan genetalia, celana dalam basah tidak segera ganti, menggunakan legging, tidak menggunakan bahan celana dalam katun, umur $<25$ tahun, tingkat pendidikan $<9$ tahun, pengetahuan kurang, cebok setelah HUS, mencukur rambut genitalia menggunakan pisau cukur manual, mengganti pembalut $<2$ kali dalam sehari. Variabel tidak mengeringkan genetalia tidak terbukti sebagai faktor risiko IMS disebabkan karena adanya pengaruh dari variabel lain yang lebih kuat dalam analisis multivariat. Pemakaian celana legging atau celana ketat tidak terbukti sebagai faktor risiko yang berpengaruh terhadap kejadian IMS pada ibu rumah tangga disebabkan proporsi responden secara keselurahan baik yang menggunakan celana legging maupun tidak menggunakan celana legging sebesar $50 \%$. Variabel celana dalam basah tidak segera 
ganti tidak terbukti berpengaruh sebagai faktor risiko IMS pada ibu rumah tangga dalam analisis multivariat disebabkan karena adanya pengaruh dari variabel lain yang lebih kuat saat dianalisis secara bersama-sama, Variabel bahan celana dalam katun tidak terbukti sebagai faktor risiko IMS pada ibu rumah tangga dalam analisis multivariat karena data yang didapatkan adalah bersifat homogen yang mana total responden didapati $83,8 \%$ responden menggunakan celana dalam berbahan katun. Tidak adanya pengaruh antara umur $<25$ tahun dengan kejadian IMS pada ibu rumah tangga karena sebagian besar responden dalam penelitian ini berumur $\geq 25$ tahun sebesar $85 \%$, variabel tingkat pendidikan tidak berpengaruh sebagai faktor risisko terhadap kejadian IMS pada ibu rumah tangga karena proporsi paparan pada kasus dan kontrol yang tidak jauh berbeda, sebagian besar responden menempuh pendidikan $\geq 9$ tahun yaitu sebesar $51,2 \%$. Tidak adanya pengaruh antara pengetahuan dengan kejadian IMS pada ibu rumah tangga karena seluruh subyek penelitian homogen yang mana pada $52,5 \%$ kasus dan $57,5 \%$ kontrol tingkat pengetahuannya baik. Variabel cebok setelah melakukan HUS tidak ada pengaruh dengan kejadian IMS pada ibu rumah tangga sebab proporsi paparan pada kelompok kasus dan kontrol tidak terdapat banyak perbedaan, pada kedua kelompok melakukan cebok setelah hubungan seksual, antara kelompok kasus dan kontrol hampir sama yaitu $95 \%$ dan 97,5\%. Tidak adanya pengaruh variabel cukur rambut genetalia dengan kejadian IMS pada ibu rumah tangga karena proporsi paparan pada kelompok kasus dan kontrol tidak terdapat banyak perbedaan yang berarti dimana kedua kelompok banyak yang melakukan pencukuran rambut genetalia, antara kelompok kasus dan kontrol hampir sama yaitu $70 \%$ dan $60 \%$. Alat cukur manual atau biasa disebut pisau cukur manual yang digunakan untuk mencukur rambut genetalia tidak memiliki pengaruh yang bermakna dengan kejadian IMS pada ibu rumah tangga. Variabel penggantian pembalut saat menstruasi kurang dari dua dalam sehari tidak berpengaruh secara signifikan dengan kejadian IMS pada ibu rumah, sebab proporsi paparan pada kelompok kasus dan kontrol hampir sama, kedua kelompok mengganti pembalut rata-rata sehari lebih dari dua kali.

\section{KESIMPULAN}

Variabel yang terbukti berpengaruh terhadap terjadinya IMS pada ibu rumah tangga adalah tidak cebok sebelum HUS, melakukan vaginal douching, pendapatan keluarga rendah $<\mathrm{UMR}$.

Variabel yang tidak terbukti berpengaruh adalah umur $<25$ tahun, tingakat pendidikan $<9$ tahun, pengetahuan kurang, keringkan genetalia, tidak segera ganti celana dalam basah, tidak menggunakan bahan katun pada celana dalam, menggunakan celana legging, mencukur rambut genitalia, menggunakan alat cukur manual, mengganti pembalut $<2$ kali dalam sehari. Tidak adanya pengaruh variabel cukur rambut genetalia dengan kejadian IMS pada ibu rumah tangga karena proporsi paparan pada kelompok kasus dan kontrol tidak terdapat banyak perbedaan yang berarti dimana kedua kelompok banyak yang melakukan pencukuran rambut genetalia,antara kelompok kasus dan kontrol hampir sama yaitu $70 \%$ dan $60 \%$. alat cukur manual atau biasa disebut pisau cukur manual yang digunakan untuk mencukur rambut genetalia tidak memiliki pengaruh yang bermakna dengan kejadian IMS pada ibu rumah tangga karena

\section{SARAN}

\section{Kepada Masyarakat}

Pada ibu rumah tangga pada saat akan melakukan hubungan seksual harus selalu membiasakan diri untuk cebok sebelum melakukan hubungan seksual., tidak melakukan vaginal douching, berusaha mencari tambahan pendapatan keluarga dengan membuka usaha kecil mikro dan menengah.

\section{Kepada Pemerintah dan Institusi Terkait}

Meningkatkan komunikasi informasi dan edukasi (KIE) tentang higiene genetalia atau kebersihan kelamin terutama tentang pentingnya menjaga kesehatan kelamin yaitu dengan cara cebok sebelum melakukan hubungan seksual, tidak melakukan vaginal douching, Pemerintah harus meningkatkan pendapatan secara umum dalam rumah tangga dengan cara meningkatkan pembinaan usaha mikro, kecil dan menengah (UMKM) pada ibu rumah tangga. 


\section{DAFTAR PUSTAKA}

WHO. Reproductive health definition diakses pada 10 januari 2015 pukul 20.00 WIB

Sjaiful FD,.Farida.Z,.Jubianto.J. Penyakit Infeksi Menular seksual. Ketiga, editor. Jakarta: FKUI; 2014; 2-175

Kemenkes RI. Pedoman Nasional Penanganan infeksi Menular Seksual. Jakarta: Ditjen PP\&PL;2011

WHO Mediacentre update Nov 2012 diakses pada 10 Januari 2015 pukul 20.10 WIB

Jennings JM, Devon J. Hensel, et al. Are social organizational factors independently associated with a current bacterial sexually transmitted infection among urban adolescents and young adults? Social Science \& Medicine. 2014;118:5260.

WHO. Sexually Transmitted Infections (STIs). Media centre Fact sheet $\mathrm{N}^{\circ} 110 ; 2013$ November 2013 diakses pada 10 januari pukul 20.00 WIB

Ditjen PP \& PL.Surveilans Terpadu Biologis dan Perilaku.Jakarta: Ditjen PP \& PL Kemankes RI;2011 Profil Dinas Kesehatan Kota Semarang ;2014

Dahlan M. Besar Sampel dan cara pengambilan sampel dalam penelitian kedokteran dan kesehatan. ed t, editor. Jakarta: Salemba Medika; 2010.

Amiri F.N, Rooshan M.H, Ahmadi M.H, Soliamani M.J. Hygiene Practices And Sexual Activity Associated With Urinary Tractus Infection In Pregnant.Eastern Mediterranean Health Journal 2009;15(1): 104-110

Wijgert D, Jonneke, Morison,Charles, et al. Epidemiologic And Social Science Bakterial Vaginosis And Vaginal Yeast, But Not Vaginal Cleansing Increase HIV Acquisition In African Woman. Journal of Acquired Immune Deficiency Syndromes. June 2008;48: 203-210

Martina J.L dan Vermun H..S. Evidence For Risk or Benefits to Womens Health.Epidemiologic ReviewsApril 2002;24(2),: 155-162

Holtgarve D.R, Crosbu R.A. Social Capital, Poverty,and Income In Equality As Predictors Of Gonorrhoea, Syphilis, Clamydia, And AIDS Case Rates In The United States. Journal of Sexual Transmitted Infection 2003.79: 62-69

Dalimonthe I. Perempuan Dalam Cengkeraman HIV/AIDS, Kajian Sosiologi Feminis Perempuan Ibu Rumah Tangga. Jurnal Sosiologi.2011;5(1):4147 